\title{
Engineering Leadership Education - The Path Forward
}

\section{Dr. Richard J. Schuhmann, The Landing School}

For two decades, Dr. Schuhmann has been affiliated with engineering leadership programs at the Pennsylvania State University and the Massachusetts Institute of Technology. He now serves as the President of the Landing School of Boatbuilding and Design in Arundel, Maine.

\section{Mr. Andrew Michael Erdman, Pennsylvania State University}

Andrew M. "Mike" Erdman received his B.S. in Engineering Science from Penn State and his M.S. from USC. Erdman has also taken courses at RPI, Union, UCLA, UCSB, MIT, and Dartmouth. At Rocketdyne (Pratt \& Whitney), he helped design the Space Shuttle. As manager of Reactor Safety Analysis, Experimental Engineering, and Fluid Dynamics Technology at KAPL (Lockheed Martin), he conducted research for Naval Reactors. He currently serves as the Walter L. Robb director of Engineering Leadership and as an instructor in Engineering Science at Penn State. Erdman has chaired the local Jaycees, Department of Social Services Advisory Council, GE Share Board, and Curling Club; and served on the Human Services Planning Council, United Way, Chamber of Commerce, and Capital Fund Drive Boards of Directors. Erdman has also lectured on leadership topics at Penn State and RPI. He returned to campus frequently as a recruiter (25 years) for GE and Lockheed Martin, serving on the Penn State College of Engineering Advisory Council, helped establish an Alumni Advisory Board, and currently serves as the President of the College of Engineering Alumni Society. Affiliations include the Penn State Alumni Association, Centre County Chapter Board of Directors, President's Club, Nittany Lion Club, ASEE, ASME, AIAA, AKC, GRCA. He has been honored with a LMC/KAPL Leadership Award, GE Phillippe Award, PSEAS Outstanding service award, Jaycee International Senatorship, and an ESM Centennial Fellowship.

\section{Dr. Jack V. Matson, Pennsylvania State University, University Park}

Emeritus Professor of Environmental Engineering, Founding Director of the Leonhard Center for the Enhancement of Engineering Education, and initiator of ELDM.

\section{Dr. Dean H. Lang, Pennsylvania State University, University Park}

Dr. Lang is currently the Associate Director of the Engineering Leadership Research Program at Penn State University. She holds a BS in Mechanical Engineering from West Virginia University, an MBA from Johns Hopkins University, and a PhD in Kinesiology with a focus on Biomechanics from Penn State University. Dr. Lang's previous professional experiences and research interests range from mechanical engineering facilities design to research that applied engineering and molecular biology approaches to the study of the skeletal response to mechanical loading. As a Mechanical Engineer, she worked on facility design projects involving mechanical systems that included heating, ventilation, air conditioning, and energy conservation systems, as well as R\&D of air conditioning equipment for Navy ships. Additional research interests include the investigation of relationships among components of the indoor environment, occupants, and energy usage. Specifically, the effects of the indoor environment on occupant health and well-being and in parallel, how socially-mediated energy-saving strategies can increase awareness of energy use and/or increase energy saving behaviors.

\section{Dr. Jeffrey G. Soper, Montreux School of Business \\ Dr. Donald H. Horner Jr., Jacksonville University}




\title{
"Engineering Leadership Education - The Path Forward"
}

\begin{abstract}
The Engineering Leadership Development program at Penn State University is concluding its $20^{\text {th }}$ year. This paper is a retrospective analysis of this history. The microcosmic Tuckman model of group development fits the macrocosmic evolution of the program and is used as a framework within which to place the experiences, observations, and perspectives of the individuals associated with its conception and direction. Examples are provided of processes, failures, successes, and lessons learned, and references are provided to quantitative works describing the results of Program assessment over time.
\end{abstract}

Introduction

The Engineering Leadership Development Program at The Pennsylvania State University was one of the pioneering university-level leadership development programs in the world. Founded in 1995 as an initiative of the Leonard Center for the Enhancement of Engineering Education, the Program has graduated over 600 students with an 18 credit-hour minor in Engineering Leadership Development.

A study conducted by Purdue University suggested that today's engineering leader must be wellversed in three dimensions, namely technical, professional, and global skills. ${ }^{1}$ While the initial focus of the Penn State Program was to address professional skill development, over the past 10 years, global competency skill development has been robustly incorporated as well. ${ }^{2,3} \mathrm{An}$ international study performed by MIT noted that the Program was one of four case studies of good practice to teach Engineering Leadership, particularly with a focus on creating the broad, global engineering skill base needed in today's engineering leaders. ${ }^{4}$ Further, studies have shown that incorporation of EC2000 accreditation criteria (which included professional skill training and other pedagogy methods) enhanced professional skills and technical performance in students. ${ }^{5}$ Anecdotally, we have found that the incorporation of global competency skills developed through real-world engineering projects further energizes students, resulting in increased dedication to both the technical and professional dimensions of leadership.

As the Program approaches its $20^{\text {th }}$ anniversary, retrospection, insight, and application of lessons learned to formulate a vision of the future are appropriate. The past and current directors of the Program have gathered together to create a joint retrospective. This retrospective is strongly influenced by the authors personal experiences both in and outside of the classroom, papers published by the collective authors through the years, extensive reviews of current student learning through pre/post course surveys ${ }^{6}$ and discussions with graduates that considered both 
the career impact of the Program as well as views of the strengths and areas where the Program could be improved. Further perspective was garnered from the Program's Advisory Board, representing key industrial partners, tasked with reviewing new initiatives to assure that these were consistent with the current needs of those who hire Program graduates.

This paper provides both a qualitative and quantitative review of the past performance and impact of this Program on current students, graduates, and the companies who hire graduates. The lessons learned are used to both suggest future enhancements of this Program, as well as to help guide the development of nascent or enhancement of existing programs at other universities.

\section{Background}

Leadership is a skill-set that is highly valued by recruiters as they peruse the graduates of universities. $^{7}$ This is clearly in response to the need for technically knowledgeable leadership in business, industry, government and the military. Engineering leadership development programs are emerging and growing across the world, particularly in the United States and Canada to meet this need. ${ }^{8}$

The need for explicit leadership training has been somewhat obscured by what we will call the false hope of tangential experiences leading to positional leadership or power. Often the leadership highlighted by students in their resumes is a positional experience, where they were elected or appointed as the vice-president, president or chair of an honorary, volunteer or fraternal organization. Too often they see this experience as a qualifying event that defines them as a real 'leader'. In fact, this is like throwing someone in a deep pool and expecting them to learn how to survive. Some do on their own, others find support from friends to make it through, some adopt poor techniques and get by with doing minimal damage, and others fail, perhaps not visibly, but fail nonetheless.

The drive for explicit leadership development is in response to the need for more than just positional leadership experiences, but rather for actual education and structured mentoring and facilitated experience in leadership leading to deep learning. What are the key attitudes and skills, how do you establish a mission and vision for a technical organization, develop a strategy and plan to achieve these, lead meetings and teams, motivate yourself and others, deal with cultural and generational differences, and effectively communicate your ideas? These are the skills that corporate recruiters are looking for ${ }^{5}$, and are often not a direct result of the types of experiences students often identify as 'leadership'.

This paper provides a road-map of how one of the pioneering engineering leadership development programs in the United States was formed, the challenges encountered, lessons learned, and the future direction that derives from these past experiences. The Program at Penn State was founded in 1995, in recognition of the importance of leadership capabilities to students and those who hire them. Over the past 20 years, there was an initiator and 4 directors of the Program. They have collaborated to chronicle the evolution of the Program and, somewhat 
surprisingly, this chronology has followed the steps of Tuckman's evolution of groups to teams, namely, the stages of 'forming', 'storming', 'norming', and 'performing' (Figure 1). ${ }^{9}$ Most recently, the Program has transitioned to another step, 're-forming and informing' that reflects the realization that the skills training developed by the Program for many undergraduate students demands a much broader audience and implementation, an implementation that requires generating new opportunities for training, covering nearly all students in the College of Engineering.

You are invited to travel on this 20-year journey, learn from the difficulties and successes those affiliated with the Program faced, and, hopefully, anticipate the potential challenges when considering starting or enhancing an existing engineering leadership development program.

Forming: 1992-1995 (Dr. Matson)

The Engineering Leadership Development Minor has had critical support from the College of Engineering's Dean's office since conception. In the beginning, 1992 to 1995, Associate Dean of Engineering, Dr. Carl Wolgemuth, was the primary responsible person in the Dean's Office with Dean Dr. David Wormley. Dr. Wolgemuth retired and Associate Dean designate, Dr. Robert Pangborn, took over through 2005. The Leonhard Center Alumni Committee, with Michael Brunner as the first Chair, and the late Dr. William Leonhard gave full backing to the Engineering Leadership Development Minor throughout its existence.

In May, 1992, Dr. Matson was recruited from the University of Houston by the Engineering College at Penn State to be the first Director of The Leonard Center for Innovation and Enhancement of Engineering Education. The stated goal of the Center was to identify the needs of the students and of the marketplace, develop curriculum innovations and teaching methods, test the innovations, and integrate the successful results into the engineering programs. Drawing on his experience developing and teaching courses in creativity, innovation, and entrepreneurship, Matson applied those lessons to the creation of the Center. In Matson's book, The Art of Innovation: Using Intelligent Fast Failure, he_suggested that innovations required a great deal of experimentation, and that much of the knowledge for success depended on the information gleaned from failures. ${ }^{10}$ That principle dominated as Matson set out to meet the goals of the Center.

In March, 1993, through much debate and discussions with the Leonard Center Advisory Board comprised of distinguished engineering alumni, faculty, students, and other interested parties, a draft Strategic Plan was created. In summary, the Plan recommended that interdisciplinary problem solving, innovation, and leadership training be fully integrated into the curriculum. Active learning involving design based experiences with minimum lectures, and maximum cooperative teamwork was to be implemented so that the students would take primary responsibility for their learning with faculty as mentors and coaches. 
Student leadership potential was to be initially explored in a pilot program involving a group of volunteer undergraduates known as the Envisioneers. This strategy was to bring the profession back to its roots in invention and innovation and allow students to express their creativity, leadership, and teamwork skills, and provide active learning skills experiences to synthesize their knowledge bases.

In 1994 discussions began within the Leonard Center relating to the creation of a "Creativity Minor". A cross-college committee was formed and the focus changed from creativity and innovation to leadership, specifically leadership for engineers. The minor would help students develop the essential leadership skills necessary in engineering, including project management, working in teams, communication skills, global awareness, green engineering, and professional ethics. ${ }^{11}$ In 1995 the Plan was crystallized by the proposal for an Engineering Leadership Development Minor (ELDM) consisting of courses in leadership, organizational and business skills, entrepreneurship, and a capstone course in science, technology and public policy. ${ }^{12}$ Creativity and innovation, although the original focus of the proposed Minor and implicitly present within these new course objectives, were explicitly absent in the Program's course titles. Undergraduate students in only a few engineering departments were allowed to take one or two of the Minor courses as technical or general electives within their major. The Minor was to be housed in the Electrical Engineering (EE) Department. The process for initiating any Minor at the University required approval at six levels, three of which were crucial: the EE Department faculty, the Engineering College Curriculum Committee, and the Faculty Senate. In caucusing with the faculty members for approvals, it was not clear that the Minor proposal would be successful. The Engineering faculty members in opposition to the proposal did not want what they perceived as non-engineering courses in the College. Several members of the Engineering Faculty Curriculum Committee thought the Minor was more appropriate in the Business School. The debate was heated, but the Minor was narrowly approved by one vote. The narrow success of the vote was a clear reflection of the views of the college. The domain of engineering leadership was new at the time, and there were no other programs available to offer to faculty as benchmarks of value or success. Reluctance, by many in the College of Engineering, to include non-technical courses at that time was not unexpected. Industry champions, incased within the Leonard Center, were critical to the acceptance of the program.

The hard work of figuring out the details of each course was then undertaken. A decision was made to experiment with the courses and maximize learning through the failures and successes encountered in the classroom; in other words, to embed creativity and innovation as core features of the pilot courses. The first two courses offered in the fall of 1995 were "Technology Based Entrepreneurship' and "Introduction to Leadership," with 28 students enrolled. Thus, the ELDM came into being as a grand idea with many experiments, difficulties, and opportunities ahead.

Storming: 1995 - 1999 (Dr. Soper) 
The institutional approval of the program, its budget, and faculty resources were just the beginning of the struggles that were faced by the program and its leadership. Following the Engineering Curriculum Committee and Faculty Senate approval, the Leonard Center had literally weeks prior to the start of the inaugural semester to transform a set of overarching objectives into a set of integrated, fully developed deliverable courses that would satisfy a diverse array of stakeholders. Many views and theories of leadership existed, making it difficult to achieve agreement on the learning objectives and pedagogy. For example, if one searches Amazon Books for "leadership", over 129,000 hits return. Searching Bing on "leadership" returns 24,000,000 hits. Fortunately, the minor had the unwavering support of two key individuals - Dr. Larry Burton, the Head of the Electrical Engineering Department, and of course, Dr. Matson, the Head of the Leonard Center and the visionary and catalyst of the program itself. Dr. Burton was both a true proponent and an active promoter of the Program across the entire University system. He also provided the academic home for the first Director, Dr. Soper. Dr. Matson was the inspirational heart of the Program and remained actively involved in the Program as they experimented with content and techniques and pushed the comfort zones of all constituent groups, students and stakeholders.

From the outset, Matson and Soper shared the desire to create and facilitate an innovative program that developed rather than merely studied leadership. A conscious decision was made to build an integrated set of ELDM courses based upon the principles of andragogy, adult learning, rather than to continue on the path of pedagogy most commonly used in the undergraduate programs. This resulted in a program more akin to executive education than traditional undergraduate education. While not readily apparent to the casual observer, each of the courses had a solid theoretical underpinning. Rather than provide an overview of leadership theory and its evolution, the program stressed leadership theories that were particularly applicable to the individual and small group situations most commonly encountered by recent graduates such as Situational Leadership and the tenants of leadership identified in The Leadership Challenge by Kouzes and Posner. Individual assessments included the MyersBriggs Type Indicator (MBTI), the Kirton Adaption-Innovation Inventory (KAI), the Fundamental Interpersonal Relations Orientation (FIRO), and the Thomas-Kilmann Conflict Mode Instrument (TKI) in combination promoting greater individual self-awareness and understanding in an individual or small group contexts. Melding Soper's Columbia executive MBA and corporate experience, the course affectionately referred to as the "mini MBA for engineers" provided an integrative perspective of accounting reporting, finance ratio analysis, marketing strategy and implementation, and management was developed where students were expected to accurately and holistically apply these tools in analyzing and solving graduate business level case studies. Lastly, the ability to effective communicate verbally, in writing and via presentations, as well as providing candid constructive feedback - both positive and negative - was stressed in each of the courses and became somewhat of a hallmark of the program amongst employers. 
Early attempts were made to assess the impact of the program. The first attempt was to utilize the Perry Scheme of Intellectual Development which was based on student's attitude towards knowledge. Our idea was that students in the Minor would trust more their "inner voices" and not external authority and come to understand there were no right answers to many problems rather than finding a right solution. Perry had a methodology to measure on a scale of one to nine as to where a student scored based on an interview process. However, the process turned out to be too cumbersome and was dropped.

We then developed two simple external measures of student knowledge gained from the Minor and compared to students who did not take the Minor: starting salaries and job positions. We observed a trend of higher starting salaries of students graduating from the Minor compared to their fellow students. Minor graduates were also accepting offers from management consulting companies like Accenture and IBM who were hiring them for their leadership and problem solving skills that transcended engineering skills. We also know that in job interviews the Minor students promoted the Minor and asked questions related to creativity and innovation of the prospective employers. A number of them were selected for special management/leadership programs in those companies. Student course ratings were also used to evaluate the program in meeting the student's perceived needs. Student feedback helped to support the existence of the program and to help guide the structure and content. ${ }^{11}$ For example, students commonly reported a need for expanded class time as important class discussions were often interrupted within a standard class period. This feedback resulted in a change to the class structure of key minor courses to one - three hour session per week. Table 1 provides a summary of assessments performed over the past 20 years and how the conclusions led to program change.

The Program overall and each course in specific had to be experiential; focusing on how to think rather than what to think, and had to create situations where participants knew what needed to be done but most probably lacked the knowledge, skills and/or abilities to accomplish what needed to be done. In the friction of such seemingly unstructured situations, teachable moments were created and in those teachable moments leadership was developed. To facilitate and monitor individual learning and development, personal leadership journals were utilized by each participant to reflect upon their experiences, discoveries, reactions, learning, and development. Departing from the traditional method when structured knowledge is first imparted and then applied, unstructured developmental situations were orchestrated, participants were then challenged to articulate what they had learned and to frame this learning into structured knowledge. In an alternative "capstone course" titled "Creativity Innovation and Change", students were challenged to determine what they needed to learn and to then create a project through which they could achieve their developmental objectives. Reflecting the iterative nature of innovation, each facet of every course in the Program was further developed and refined every time it was delivered. Expectations for development objectives and student performance were continuously raised within this loosely structured environment. 
The Leonard Center's goal was to build a program with the intended impact to develop creative and innovative engineering leaders and from the Director-as-participant perspective it was quite successful in so doing. But not all of the impact resulting from the Program was as intended. Some of the other constituent groups and stakeholders were not so convinced. Many faculty members and administrators questioned the break from traditional pedagogical methods. Where the Program strove to develop "leadership" firm in the conviction that leadership was a capability that could be developed in a great many, others wanted to create a more elitist program for "leaders." Where the Program challenged each and every participant to grow as individuals in a variety of contexts filled with volatility, uncertainty, complexity, and ambiguity, others wanted to broaden the reach of the Program by embracing a more traditional classroom approach of a single right answer to a uniform set of givens. Where the Program drove participants to know themselves, others suggested that the Program predominantly emphasize and test on the popular theories of leadership. Conflict was frequent and intense as stakeholders on both ends of the spectrum defended their principles and worldviews through dialectic debates that opened the minds of the students in the Minor.

The period of storming was one of the most tumultuous in the history of the Engineering Leadership Development Minor escalating across the entire span of Soper's time as director of the Program. At every juncture, the Program's leaders remained true to their beliefs and to what they deemed most appropriate for facilitating the development of leadership in the student participants, namely a focus on creativity and innovation. At every juncture, the Program faced questions and resistance. It became evident that an alignment of outcomes and methodologies was in order if the Program was to continue and grow into the one intended, with engineering and leadership as its core vision. Ultimately, and to this end Soper was unwilling to acquiesce to the vision of the dominant stakeholders and his contract was not renewed. As happens in most startups, and this was a startup, the visionaries were replaced and new blood brought in.

Norming: 1999-2005 (Dr. Horner)

Armed conflict. Upon arriving as the new Director of the ELDM on June $2^{\text {nd }}, 2000$, that's what Dr. Horner found: armed conflict. As a former Army battalion commander with service during hostilities in Bosnia and Panama, Horner was no stranger to struggles between combatants. But, this was a different type of struggle, a different type of conflict. This was competition between the "hippies" and the "government", and the weapons of choice were ideas and approaches to learning.

The hippies were led by ELDM founder and urban legend Dr. Matson. Matson had managed to establish the leadership minor as a worthwhile - though misunderstood - companion to the engineering undergraduate core. Although approved by the College of Engineering hierarchy, some did not embrace the purpose of the minor and how it would complement traditional undergraduate engineering education. 
Dr. Matson's protégé was Dr. Soper, who relished his role in creating and building the program. Soper's pragmatic and edgy, approach to leadership development struck a chord with what became a core group of leadership aficionados. The following was cult-like, and students enrolled in ELDM soon established their own student group, "Engineering Leadership Development Unlimited (ELDU)," as a largely self-directed learning laboratory to further practice the leadership being taught in the classroom. Classic in-group / out-group dynamics followed, the sort of which Matson knew would eventually lead to debate, tension, and conflict between those who "knew" - the hippies - and administrators in the College of Engineering who had not yet bought-in to the essence of ELDM - the government.

The educational, ideational tension Horner encountered upon arrival had manifested during the search process. And, since it would be approximately six-months from the time Dr. Horner was named as the new ELDM Director (i.e., January 2000) until his June arrival, there was plenty of time to contemplate a positive approach for bringing the hippies and the government together. As an outsider and observer, Horner knew both camps had elements of accuracy in their respective approaches to leadership. The hippies championed creativity and minimal structure as fundamental to their learning leadership. The government wanted a leadership curriculum based on rigor and science that would complement and not compete with undergraduate engineering education. Horner's task: bring the two sides together while developing normative behaviors and practices that furthered the legitimacy of the program without dampening students' enthusiasm for learning and practicing leadership.

ELDU students were fond of reciting: "What do you want to do? How do you want to do it? How are you going to measure what you did?" The hippies had, simplified leadership to three actionable questions because central to their approach was that leadership had to be practiced to be learned, and good leaders measured what they did. Occasionally but with less vigor, ELDU students would cite an occasional passage from Kouzes and Posner's The Leadership Challenge - the text was sort of their version of Mao's little red book.

Horner embraced the students' passion for leadership by doing while bombarding them with readings on various leadership theories, styles, and approaches. In a field with well over 30,000 published studies on motivation and methods for converting groups into teams, there was no lack of sources to choose from. Students were immersed and became conversant in transformational, transactional, path-goal, contingency, and a host of mainstream leadership theories. They learned the stages of group development, personality and temperament, and how to diagnose situations and apply motivation by consequences - i.e., reward, punishment, extinction, and negative reinforcement - as part of their ELDM coursework.

Early on, Horner recruited Dr. Brighten, former Penn State Provost, to teach courses in the leadership minor. As a world class engineer and pioneer in the design of the "Penn State mechanical heart," Dr. Brighten immediately brought enormous legitimacy to the program - both inside the College of Engineering and throughout Penn State. Joining Brighten were additional 
credentialed professionals and entrepreneurs such as Dr. Wesley Donahue, who completed his doctoral dissertation with the assistance from Dr. Soper and the Leonard Center, and Robert Beaury, and then doctoral candidate Richard Schuhmann. These ELDM instructors embodied a duality that appealed to both the hippies and the government. Students enjoyed and embraced the real world rigor and knowledge based approaches the ELDM instructors could recount from their own first-hand experiences. Administrators in the College of Engineering were likewise pleased - and perhaps a bit surprised - to see that leadership was, after all, a scientific enterprise which would be incorporated into traditional engineering education. This process took about five years, but by January 2005 the ELDM had become legitimate in the traditional academic perspective. As was envisioned by each of Horner's predecessors, it was now normal to study leadership in the context of engineering, and the number of students taking courses in ELDM exploded to $\sim 100$ each semester.

Performing: 2005 - 2012 (Dr. Schuhmann)

Dr. Horner's considerate and empathic leadership had healed the open wounds left by early skirmishes and bolstered physical and social structures such that by December 2004, the Engineering Leadership Development Minor had settled into a comfortable steady state. The courses defined in 1995 had been offered for a decade and now resembled their original definition. Program faculty were comfortable with the content and approach. Students had formed a picture of the associated objectives and outcomes. College leadership and faculty were familiar with the ELD Minor and generally accepting of its value to students; however, the Program was still not viewed as being a truly integral part of the College of Engineering because the course material - leadership - still remained seen as external and unrelated to any departmental curriculum. Although multiple nuanced perspectives still remained regarding the identity of the ELD Minor, the goal of the Minor in its broadest sense, to promote leadership development in students, was clearly established and widely accepted. The decadal milestone and a transition in Program Directors from Dr. Horner to Dr. Schuhmann in January 2005 inspired an introspective review of the Program's history, current state, and future direction.

The first question program faculty posed during the 2005 review was regarding the fundamental definition of engineering leadership, a term that featured prominently in the program title. Did developing leadership capabilities in students within the College of Engineering constitute "engineering leadership", or was a more robust engineering-centric approach and content required? Industry advisory boards at the University supported the proposition that the development of leadership skills in engineering graduates was a priority; however, there was no definition much less consensus forthcoming regarding the distinction or definition of "engineering leadership". Program faculty benchmarked literature and held discussions over a 1year period and developed a suite of engineering leadership educational objectives and outcomes that were mapped to the existing curriculum ${ }^{12}$. 
Between 2000 and 2005, many quality leadership-related simulations (e.g. Star Power; Kivulini) had been integrated within the leadership curriculum and effectively employed in the classroom. Although some simulations were engineering-centric, many were not. Consideration was given to expanding these classroom simulation experiences, enhancing the engineering content, or developing a new approach. Upon review, faculty determined that, like a SCUBA diver-intraining is able to develop a fundamental skill set by practicing with equipment in a classroom simulation or even in a swimming pool, there is no substitute for subsequent non-simulated realworld "sub-sea" experiences. Problem based undergraduate experiences were developed that were specific (i.e. possessed a stakeholder), measurable (i.e. students could demonstrate progress even if incremental), and realistic (i.e. expectations of results that could realistically be achieved in the allocated time). Projects were extremely well defined by instructors on the front end, while remaining open-ended on the back, thus allowing students the freedom to experiment, fail, and learn. Students were challenged in courses to explore and understand the root cause of the problem they were assigned, the sustainability of technical solutions, and consider the ethics of proposed actions; these objectives harking back to the intent as described in 1996.

Assessments conducted in the Program's International Leadership of Engineering and Development course highlighted the value of virtual international collaboration but also pointed toward the need for travel-based experiences. These results led to the expansion of virtual and travel activities. ${ }^{2}$ The perceived need for enhanced global awareness and enhanced worldview integrated within the leadership curriculum drove an investigation into how best to deliver these capabilities in a university environment, specifically how these might be accomplished through real-world problem based learning. Relationships were formed with international universities from countries not normally found in a collaborative suite typical of a US university. A relationship with Corvinus University in Budapest, Hungary resulted in a collaborative class that paired Penn State engineering students with Corvinus University business students on projects in a third country, usually in the developing world. This facilitated the development of crosscultural and cross-disciplinary collaborative skills, leveraging technology for virtual team building processes, and requiring a formal consulting report (and sometimes physical prototypes) as part of the array of course outcomes. ${ }^{2}$ Another relationship with L'École Mohammadia d'ingénieurs University in Rabat, Morocco allowed cross-cultural collaborative skills development in collocated teams of multidisciplinary engineering students. This course required more depth in cultural preparation (e.g. language, geopolitics) because of the destination and requirement to execute and operate the project wholly in this international venue. Because the student groups were for the most part engineering students (a small percentage of Penn State students were not from the college of engineering), the projects students engaged in generally allowed for more technical depth than those with Corvinus University. The limited time available for the collocated experience resulted in less emphasis on written documentation and reporting and more on peer-to-peer interactions and physical prototyping of technology. ${ }^{13}$ In more recent years, 2012 to 2014, relationships have been extended to include collaboration with Université d'Abomey -Calavi in Cotonou, Benin, Taibah University in Medina, KSA and KU Leuven in 
Brussels, Belgium. Partnerships continue to be developed to provide additional opportunities for student engagement in cultural exchanges.

The integration of global skills, broadly recognized by College of Engineering faculty yet difficult to integrate on a departmental level, combined with the strong technical core of those experiences, gave a greater sense of legitimacy to these courses and facilitated their acceptance by engineering departments across the college, both philosophically, and pragmatically as technical electives; this is especially important given the already challenging nature of degree requirements for many engineering students.

Between 2005 and 2014 the Program implemented assessment instruments within multiple courses and program faculty were assessing student-defined educational expectations to see how these mapped to the existing curriculum. The Program had increased its efficiency, expanded into different delivery modes and content, and increased its course offerings with a robust global engineering leadership track. Assessments had been implemented, papers authored (summarized in Table 1), invitations to share Program practices received from domestic and international forums, and the Program's international initiatives were featured on the cover of the college of engineering magazine for three consecutive years $(2010,2011,2012)$. Virtual teaming, initiated and piloted within the School of Engineering Design, matured within the Engineering Leadership Program and was subsequently adopted by mechanical and industrial engineering to enhance the education of students within those departments. The University adopted a course developed by the Engineering Leadership Program to prepare students for international collaborations; this one-credit course was offered in an online version to all resident Penn State students in preparation for international semester abroad, courses, or internship experiences. In 2011-2012, six students completed Honors theses through the Program in civil engineering (2), engineering science (1), and engineering leadership (3). The Program was performing - as an accepted member of the College of Engineering, and as an exemplar.

\section{Informing: 2012-2015 (Mike Erdman)}

The 20 year history of the ELDM Program at Penn State has seen many successes, and some difficulties. Overall, the Program has been an outstanding success, with over 600 graduates, many of whom have gone on to stellar careers leading engineering efforts. However, during that period of time, the University has graduated approximately 20,000 engineers, the overwhelming majority of whom had not had an opportunity to benefit from this Program.

So, while performance has continued to be tracked and improvements pursued, enhancing the scope of the Program is perhaps the most pressing need that the current Program Director, Mike Erdman, is addressing. 
At the undergraduate level, the number of students benefitting from the existing Program has averaged about 80 per year, roughly half of whom complete the full minor. Based on a growing demand, driven by greater awareness, class size ramped up such that in the spring of 2015, two sections were required, with twice the average enrollment of the past. The Program has recently introduced Lion Leadership Lessons, a series of video vignettes on leadership topics that will be provided to the instructors of the freshmen seminar series. This will provide basic leadership, teaming, and ethics training to all incoming freshmen to the College of Engineering. Further, the Program will activate a currently approved (yet never offered at the main campus) certificate in Engineering Leadership that will allow up to another 80 students per year to benefit from many of the leadership courses without committing to a full 18 credit minor. At the undergraduate level, this will result in annually providing basic leadership training to approximately 2000 students through the freshmen seminar series, 80 students with the certificate, 80 with the full minor, and another 80 who take some leadership courses as electives.

At the graduate level, there has been no program available. Certainly the need for leadership training for master and doctoral students is as great as it is for bachelor students. In fact, many companies expect that these individuals with advanced degrees will rise to leadership positions. In the fall of 2014, Penn State began to develop a Master of Engineering Leadership and Intrapreneurship (MELI) Program, with an emphasis on applying leadership and entrepreneurship skills within existing corporate structures. Two new graduate level courses were initially offered in the spring semester of 2015, and two additional courses are being developed for initial offering in the upcoming fall 2015 semester. By spring 2016, it is anticipated that the full Master Program will be available for an initial cohort of 20 students. Within 4 years it is expected that the number of cohorts will double. In addition, a graduate certificate in Engineering Leadership will be developed such that those who want experience in leadership but are interested in pursuing a more technical master or doctoral program will have that option. As the graduate Program reaches a "steady state" condition, it is expected to have 40 to 50 students enrolled in the MELI Program and another 40 to 50 students in a graduate certificate Program.

Finally, an additional goal of the Program is to further expand its scope by making this training available on-line through the highly rated Penn State World Campus programs. The Program will start this pursuit in academic year 2015/16 with an eye toward having it on-line by the following academic year. This will provide an opportunity for employees and students unable to relocate to University Park to benefit from the various courses and programs being developed.

Now, to apply the lessons learned from the 20 years of evolution of the full undergraduate minor. First, a vision and the buy-in of the key stakeholders is an absolute necessity. The Dean and the Associate Deans in the College of Engineering are fully appraised and supportive of these initiatives, so much so that they have invested considerable time and funding to support the development of these programs. 
Secondly, the Program's industrial partners, who hire the majority of Program students, must be partners as well in the development of these programs. Without a clear consensus on the direction and content of these programs, the Program may not be consistent with their needs and their financial and moral support will be lacking. An industrial advisory board has been formed with representatives from key supporters, ranging from CEOs to HR managers to first line supervisors. They have actively engaged in reviewing programs and working with faculty and students to assure that the new programs are properly focused, and that the existing programs continue to evolve to meet the changing needs of those who hire the Program's students.

Thirdly, lessons learned through assessments/feedback must be applied to continue to refine and improve program content and delivery. During the Informing period, performance has continued to be tracked using feedback from assessments to help evolve program content. In a study of learner expectations and outcomes within the Program's Engineering Leadership Principles course, a strong relationship was observed between student expectations for learning and improved understanding. ${ }^{6}$ Study results indicated that if students were aware of their learning expectations they were more likely to learn. These results suggest the need to clearly identify and manage student expectations to encourage learning and led to modifications in course delivery to better manage student expectations. Assessments in the Program's International Leadership of Engineering and Development course led to a sensitivity to address students concerns about uncertainty resulting in modifications to course content to increase students' awareness of uncertainty and tools to better manage uncertainty through clearly developed international team charters. ${ }^{3}$ Recent assessment results (unpublished ${ }^{16}$ ) indicate that some areas of the program have been very successful such as program content aimed at increasing students' verbal communication skills. Data will be analyzed to identify areas where further emphasis should focus to better achieve learning outcomes.

Finally, alignment within the program is key. Adequate staffing, administrative support, student engagement, international collaborations are required if these dramatic changes are to succeed. The program has moved from one full-time director with 3 part-time instructors and a fraction of an admin to adding an Associate Director for Engineering Leadership Research, a full-time administrative support person, and posting a position for an Associate Director for Engineering Leadership Outreach. Further, as the number of enrollments increases, full-time instructors will be added. A student organization, the Engineering Leadership Society, has been formed which provides program feedback from a student perspective, as well as serving as a magnet to attract some of the emerging, self-selected leaders from the student body. And finally, international collaboration has been expanded from one university to five, and the Program continues to look for additional opportunities for international experiences for students and critical input from academic partners.

Conclusions 
The Penn State Engineering Leadership Development Program's 20 year journey continues to be a work-in-progress. Fortunately, the Program has had a solid base to build upon, with lessons learned that have helped to shape its future. Just as a group may not evolve into a team without the dreamy optimism of forming, the turbulence of storming, the empathy and conciliation of norming, the Engineering Leadership Development Program owes its current state of preeminence to those Program Directors and stakeholders, past and present, who fought, each in his own way, to make the Program one of excellence for their students. It is hoped that these lessons will be valuable in your journey, whether it be to develop a new leadership development program, to overcome adversities in an existing program, or to define plans for future enhancements (Figure 1).

\section{Forming}

A fundamental requirement is to have a capable, tenacious, knowledgeable individual (i.e. a zealot), well versed in the workings and leadership of the college and university, to drive the development of the program. He/she will need to overcome inevitable resistance from faculty who are concerned that the inclusion of "soft" skills will detract from the classic, technology focused engineering curriculum. Further, there needs to be a high level of institutional support from within the college, and even within the university. A new program in leadership will require funding as well as capable and experienced faculty. It may also be perceived as encroaching on turf that has a home in the business or psychology schools. These road-blocks will call on the zealot to navigate a successful path.

\section{Storming}

During the storming phase, achieving agreement on the learning objectives and pedagogy is essential. The key is to develop a good understanding of the customer's needs and use this as your compass. What does engineering leadership mean to those who hire our students? And finally, expect that changes in the content of the program and its leadership are both inevitable and positive. Evolving the curriculum to meet the changing landscape of our engineering profession is healthy, and incorporation of new perspectives can infuse new energy and vitality. But, as Machiavelli noted in the $15^{\text {th }}$ century, "there is nothing more difficult and dangerous, or more doubtful of success, than an attempt to introduce a new order of things in any state”. While change is critical to the evolution and success of a leadership program, unless one's vision is defined and clearly and openly communicated, excluded stakeholders can be expected to offer resistance, and once trust is lost it is extremely difficult to regain.

\section{Norming}

During the norming phase, the program needs to continue to evolve to meet the changing landscape. It is critical to continue to build legitimacy by infusing the program with theory while 
instilling the learning objectives with action. During this phase, constructive conflict can be positive and result in system improvements. It is when conflict degenerates to an affective state, an "us vs. them", that endless do-loops may result, doing damage to the system. Rapid, intelligent management of constructive conflict and resolution of affective conflict is critical for programs moving through the evolutionary process. Alignment of stakeholders can only be accomplished through dedicated communication and open sharing of concerns and solutions by all parties.

\section{Performing}

Assessment of curricular efficacy must be woven into the program to assure delivery of value. This includes assessing individual courses for achievement of learning outcomes, as well as input from graduates of the program. A desire for introspection and a self-critical attitude are essential for this feedback to affect change. Leadership assessment techniques are under development at a number of universities, and this fertile ground needs to be continually reviewed for new and improved methods. We firmly believe that a good assessment, done regularly, with feedback turned back into improvement actions, although not necessarily the perfect vehicle, is far better than no assessment at all. Further, interaction with other leadership programs, both within the university, other universities with engineering leadership programs, and internationally provide both broadening experiences for students as well as perspectives on international and crosscultural skills. Finally, an important tool in properly staging your program evolution is to continually assess, improve, clarify and communicate your objectives.

\section{Informing}

The value of customer input has been highlighted in this paper. Institutionalization of this feedback via standing committees or boards (such as student and alumni organizations, industrial advisory boards) and consistency of assessment tools to allow tracking trends can facilitate this feedback. Because of the pervasive need, in today's world, for engineers to learn to be both technically well-versed, able to manage their own work as well as in many cases that of others, establish new directions and lead change, and work in a global context, a broad scope of engineering leadership programs is becoming more important. Within the Penn State Engineering Leadership Development program, plans are underway to expand the reach to undergraduates and to offer both residential and online Engineering Leadership graduate programs. The development of funding and staffing to support this enrichment of programs often goes hand-in-hand with the effective assessment and broadening of scope.

\section{Generic Lessons Learned}

The experience of 20 years of engineering leadership education at Penn State has created some overarching findings. Experiential learning is a key to bringing the lessons in leadership into practice and retention; simulations, while possessing value, are in and of themselves insufficient vehicles for effective learning. Invited guest lecturers, those who have successfully fought the 
battles and have developed their own unique view of what makes a successful leader are invaluable in exposing the student to the myriad of techniques that may work for the mix of their personal strengths, the team and the situation. Multidisciplinary and multicultural engagement on teams and in the classroom helps to prepare the students for today's global engineering environment. And, finally, engage your customers, in the broadest sense (students and those who hire them, alumni), in periodically reviewing your mission, vision and strategy.

Figure 1: A 20 Year Journey: Lessons Learned.

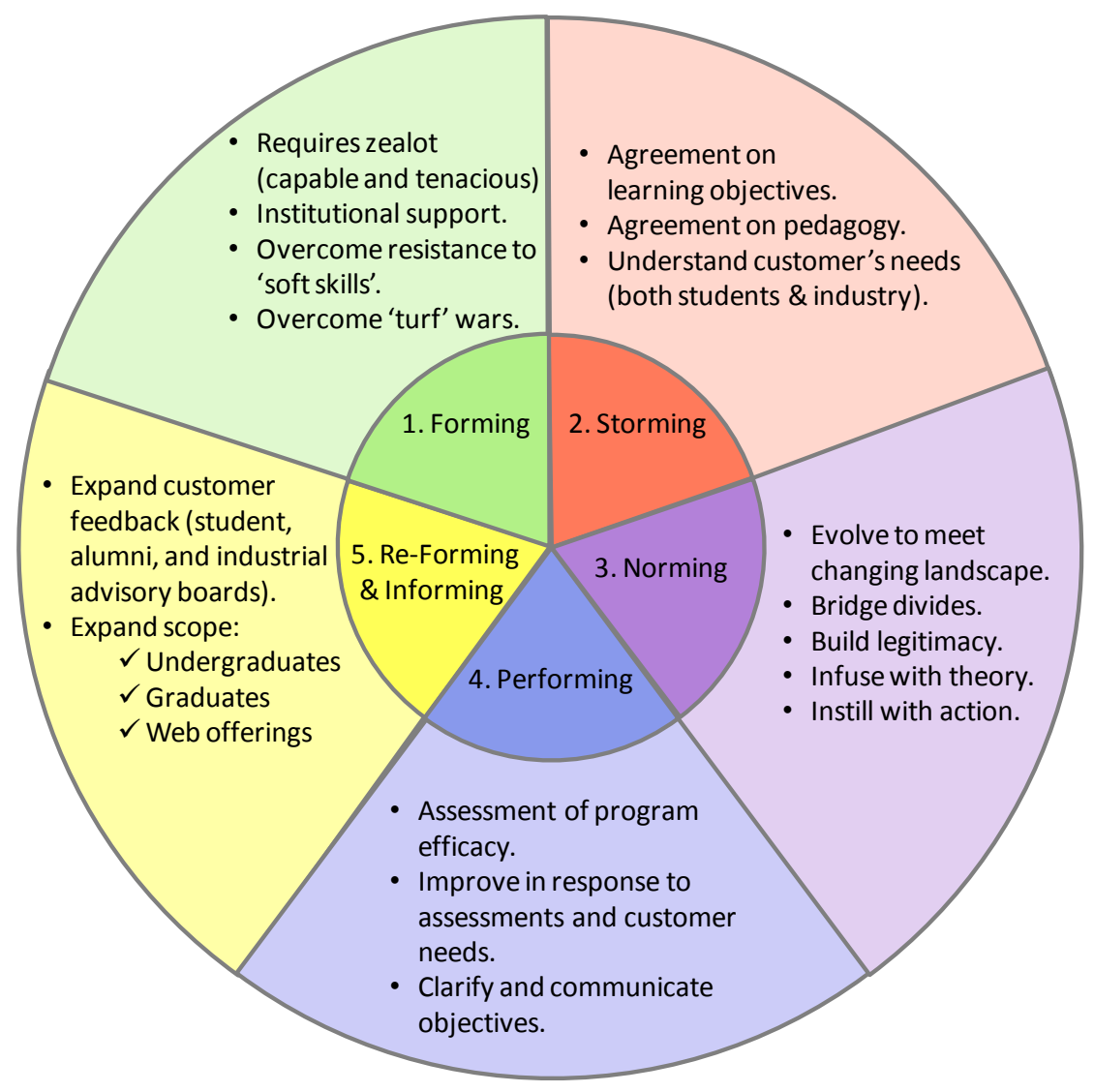

\begin{tabular}{|c|c|c|c|c|}
\hline $\begin{array}{c}\text { Year of } \\
\text { Assessment }\end{array}$ & Assessed & $\begin{array}{c}\text { Type of } \\
\text { Assessment }\end{array}$ & Key Conclusions & Program Implications \\
\hline 1995-1996 & Program & $\begin{array}{l}{ }^{11} \text { Student } \\
\text { feedback and } \\
\text { program status }\end{array}$ & $\begin{array}{l}\text { Students appreciated the } \\
\text { value of the oral and written } \\
\text { requirements and derived } \\
\text { personal benefits. Short } \\
\text { duration class sessions } \\
\text { interrupted critical } \\
\text { discussions. }\end{array}$ & $\begin{array}{l}\text { Feedback supported } \\
\text { existence of Program. } \\
\text { Feedback changed class } \\
\text { structure of key courses } \\
\text { to one } 3 \text { hour session per } \\
\text { week. }\end{array}$ \\
\hline $2005-2006$ & Program & $\begin{array}{l}{ }^{12} \text { Benchmark of } \\
\text { salient literature, }\end{array}$ & $\begin{array}{l}18 \text { educational objectives and } \\
\text { outcomes identified for }\end{array}$ & $\begin{array}{l}\text { Mapped objectives and } \\
\text { outcomes to curriculum }\end{array}$ \\
\hline
\end{tabular}




\begin{tabular}{|c|c|c|c|c|}
\hline & & $\begin{array}{l}\text { definition of } \\
\text { objectives and } \\
\text { outcomes and } \\
\text { curriculum } \\
\text { mapping }\end{array}$ & engineering leadership. & $\begin{array}{l}\text { and modified and grew to } \\
\text { close gaps. }\end{array}$ \\
\hline 2006 & Program & $\begin{array}{l}{ }^{14} \text { PSEAS data } \\
2000-2002\end{array}$ & $\begin{array}{l}\text { Leadership skills reported to } \\
\text { be of significant value to } \\
\text { alumni. }\end{array}$ & $\begin{array}{l}\text { Supported existence and } \\
\text { salience of Program to } \\
\text { engineering faculty and } \\
\text { community. }\end{array}$ \\
\hline 2008 & $\begin{array}{l}\text { International } \\
\text { Leadership of } \\
\text { Engineering } \\
\text { and } \\
\text { Development } \\
\text { (ENGR } \\
420 / 422 \text { ) }\end{array}$ & $\begin{array}{l}{ }^{2} \text { Post-course } \\
\text { assessment of } \\
\text { student learning } \\
\text { outcomes }\end{array}$ & $\begin{array}{l}\text { There is significant value to } \\
\text { students in virtual } \\
\text { international collaboration; } \\
\text { however, there is no } \\
\text { replacement for travel-base } \\
\text { experiences. }\end{array}$ & $\begin{array}{l}\text { Maintain and expand } \\
\text { virtual and travel } \\
\text { activities. }\end{array}$ \\
\hline 2009 & $\begin{array}{l}\text { International } \\
\text { Leadership of } \\
\text { Engineering } \\
\text { and } \\
\text { Development } \\
\text { (ENGR } \\
420 / 422 \text { ) }\end{array}$ & $\begin{array}{l}{ }^{15} \text { Assessment of } \\
\text { student project } \\
\text { design outcomes } \\
\text { from } 2006 \text { - } 2009\end{array}$ & $\begin{array}{l}\text { The relative importance of } \\
\text { appropriate design, green } \\
\text { design, economic } \\
\text { development, and social } \\
\text { development are evaluated } \\
\text { for } 2 \text { years of international } \\
\text { collaborative courses. }\end{array}$ & $\begin{array}{l}\text { There are } 4 \text { categories } \\
\text { that designs should be } \\
\text { measured by: appropriate } \\
\text { design, green design, } \\
\text { economic development, } \\
\text { and social development. } \\
\text { There must be a } \\
\text { recognition that design } \\
\text { parameters such as } \\
\text { efficiency may need to be } \\
\text { sacrificed in order to } \\
\text { provide an appropriate } \\
\text { solution that does no } \\
\text { harm. }\end{array}$ \\
\hline $2011-2013$ & $\begin{array}{l}\text { Leadership } \\
\text { Principles } \\
\text { (ENGR 408) }\end{array}$ & $\begin{array}{l}{ }^{6} \text { Assessment of } \\
\text { student } \\
\text { leadership } \\
\text { learning } \\
\text { outcomes }\end{array}$ & $\begin{array}{l}\text { Strong Relationship between } \\
\text { student expectations for } \\
\text { learning and improved } \\
\text { understanding. The class } \\
\text { positively changed the } \\
\text { students' performance in } \\
\text { these attributes. }\end{array}$ & $\begin{array}{l}\text { Clearly identify and } \\
\text { manage student } \\
\text { expectations to } \\
\text { encourage learning }\end{array}$ \\
\hline $2013-2014$ & $\begin{array}{l}\text { International } \\
\text { Leadership of } \\
\text { Engineering } \\
\text { and } \\
\text { Development } \\
\text { (ENGR } \\
420 / 422 \text { ) }\end{array}$ & $\begin{array}{l}{ }^{3} \text { Assessment of } \\
\text { accommodation } \\
\text { of students to } \\
\text { virtual teaming } \\
\text { across } \\
\text { international } \\
\text { boundaries }\end{array}$ & $\begin{array}{l}\text { Virtual international teaming } \\
\text { experiences served to } \\
\text { normalize student } \\
\text { expectations in time } \\
\text { management, concern over } \\
\text { belonging to a group or being } \\
\text { independent, and openly } \\
\text { expressing opinions. }\end{array}$ & $\begin{array}{l}\text { Additional improvements } \\
\text { in student learning and } \\
\text { team performance are } \\
\text { possible with better } \\
\text { cross-national team } \\
\text { communications of } \\
\text { expectations, } \\
\text { responsibilities, } \\
\text { deliverables, feedback }\end{array}$ \\
\hline $2012-2015$ & $\begin{array}{l}\text { Leadership } \\
\text { Principles } \\
\text { (ENGR 408) }\end{array}$ & $\begin{array}{l}{ }^{16} \text { Student } \\
\text { assessment of } \\
\text { skill development }\end{array}$ & $\begin{array}{l}\text { Average improvement in } 16 \\
\text { leadership skills (e.g. ethics, } \\
\text { cultural awareness, } \\
\text { communications, } \\
\text { organizational leadership, } \\
\text { self-knowledge, creativity and }\end{array}$ & $\begin{array}{l}\text { Expand assessment to all } \\
\text { leadership courses on a } \\
\text { regular basis and track } \\
\text { changes over time to } \\
\text { assure program continues } \\
\text { to meet expectations. }\end{array}$ \\
\hline
\end{tabular}




\begin{tabular}{|c|c|c|c|c|}
\hline & & & $\begin{array}{l}\text { teamwork) is } 4.4 \text { on a Likert } \\
\text { scale of } 1 \text { to } 5 \text {; maximum is } \\
4.9 \text { on improving oral } \\
\text { presentation skills }\end{array}$ & $\begin{array}{l}\text { Modify assessment tools } \\
\text { as clarity in student, } \\
\text { graduate and industrial } \\
\text { partner's needs evolve. }\end{array}$ \\
\hline
\end{tabular}

Bibliography

${ }^{1}$ Allert B.I., Atkinson D. L., Groll E. A., and Hirleman E. D. Making the Case for Global Engineering: Building Foreign Lanuguage Collaborations for Designing, Implementing, and Assessing Programs. Online Journal for Global Engineering Education, Vol. 2 (2007), Iss. 2, Art. 1.

${ }^{2}$ Schuhmann, R.J., S. Zappe, "Shaping the World: Teaching Global Leadership Skills to Engineers”, ASEE Global Colloquium, Cape Town, South Africa, October 2008.

${ }^{3}$ Gordon, A., Schuhmann, R.J., Devon, R.F., Erdman, A.M. and Atieh, A. Cultural Accommodation in Virtual Engineering Academic Teams. ASEE International Forum, Indianapolis, IN, June 2014.

${ }^{4}$ Graham R. Crawley E., and Mendelsohn B.R. Engineering leadership education: A snapshot review of international good practice. (2009).

${ }^{5}$ Lattuca L.R., Terenzini P.T., Volkwein J.F. Engineering change: a study of the impact of EC2000. (2006) ABET, Inc., Baltimore, MD.

${ }^{6}$ Hochstedt K.S., Erdman A.M., Schuhmann R.J. Learning Expectations and Outcomes for an Engineering Leadership Principles Class. ASEE Annual Conference \& Exposition, June 2013.

${ }^{7}$ Levy A. Recruiting an Engineer: Top Qualities to Look for in Applicants. http://www.engineeringrecruiting.net/?p=54 Accessed 1-30-15.

${ }^{8}$ The development of the leadership division for ASEE. https://aseelead.wordpress.com/.

${ }^{9}$ Tuckman, Bruce W., “Developmental Sequence in Small Groups”, Psychological Bulletin, 63, 384-399, 1965.

${ }^{10}$ Matson, J.V., "The Art of Innovation: Using Intelligent Fast Failure”, The Pennsylvania State University, 1991.

${ }^{11}$ Burton L.C., Soper J. G., and Matson J. V. Penn State's Engineering Leadership Development Minor. Conference on Frontiers in Education - FECS , vol. 3, pp. 1129-1131, 1996. 
${ }^{12}$ Schuhmann, R.J. "Engineering Leadership Education: The Search for Definition and a Curricular Approach", Journal of Science, Technology, Engineering and Mathematics Education, Bol. 11, No. 3 (2010).

${ }^{13}$ Kosowatz, J., "Innovation Helps Process the Baobab Fruit", ASME Engineering Topics online, 2012.

${ }^{14}$ Devon, R., Kisenwether, E., Schuhmann, R., Pangborn, R., and Barron, K. Engineering Education and the Global Economy: The Search for Policy, ASEE, 2006.

${ }^{15}$ Schuhmann, R.J., Nadadur, G., Csapo, K. International Collaborations - The Dimensions of Socially Responsible Engineering Design. 1st Global Colloquium on Project Oriented Engineering Education, Technische Universität Berlin, Berlin, Germany, October 2009.

${ }^{16}$ Erdman, A.M. Student assessment of skill development in Leadership Principles course. To be published. 